\title{
The Speech Act Theory in English and Arabic
}

\author{
Fareed Hameed Al-Hindawi' ${ }^{1}$, Hameed Hasoon Al-Masu'di' ${ }^{1}$ Ramia Fua'd Mirza ${ }^{2}$ \\ ${ }^{1}$ English Department, College of Education for Human Sciences, University of Babylon, Babylon, Iraq \\ ${ }^{2}$ English Department, Faculty of Arts, University of Kufa, Najaf, Iraq \\ Email: ramai.mir@gmail.com
}

Received 15 September 2013; revised 16 October 2013; accepted 25 October 2013

Copyright (C 2014 by authors and Scientific Research Publishing Inc.

This work is licensed under the Creative Commons Attribution International License (CC BY).

http://creativecommons.org/licenses/by/4.0/

(c) (i) Open Access

\begin{abstract}
This paper is mainly concerned with proving that it is not Wittgenstein, the German philosopher, who actually seeded the main gist of the Speech Act Theory; there are others who preceded him (and all those who followed him, the first of whom is Austin) in doing so: Arab scholars. Accordingly, this work starts by reviewing the most basic ideas of the original theory proposed by Austin and developed by Searle. The basic ideas presented by the Arabic theory are presented in the second section, and then a contrast between the two is made.
\end{abstract}

\section{Keywords}

Austin; Searle; As-Sakkaki; Al-Jurjani; Constatives and Performatives According to Najaf School of Jurisprudents

\section{Introduction}

The Speech Act Theory is a reputable pragmatic concept that has been imbued with research since its first appearance in 1962 till now. Any pragmatic paper, thesis or book, makes reference to it, or some of its parts, in one way or another, hence showing its importance in the pragmatic literature.

The historical tracers of this theory state that it has been first engendered by Wittgenstein, the German philosopher, but has been given some linguistic tint by Austin and Searle, later on.

However, the present paper makes its appeal to prove that it is not Wittgenstein who actually seeded the main gist of the theory; there are others who preceded him (and all those who followed him) in doing so: Arab scholars.

Accordingly, this work starts by reviewing the most basic ideas of the original theory proposed by Austin and developed by Searle. The basic ideas presented by the Arabic theory are presented in the second section, and 
then a contrast between the two is made.

The contrast has proved that Arab scholars have presented this theory long before their western counterparts. Moreover, there are some differences which make the Arabic theory more mature than the western version.

\section{Speech Act Theory in English (SATE)}

Historically speaking, the German philosopher Ludwig Wittgenstein is the first to say that the meaning of language depends on its actual use. For him, in ordinary life, language is used like a game because it consists of rules which, when followed, result in "doing” things. Like ordinary games, such as chess, each language game has its own rules the application of which leads to a different result (Littlejohn, 2003: pp. 77-78). In other words, SATE has been seeded by the hands of philosophers, not linguists, the opinion which Levinson (1983: p. 227) asserts.

In spite of the fact that the speech act theory has been foreshadowed by Wittgenstein, it is usually attributed to the Oxford philosopher Austin in 1962. His ideas, then, have been refined, systematized and advanced by his stuedent, the American philosopher, Searle (1969, 1975, 1977). It follows that SATE will be discussed by its two principal advocators: Austin and Searle.

\subsection{Austin's Version}

To start with, Austin starts his widely cited work by distinguishing between "statements which he prefers to call "constatives” and another type of utterances which he calls performatives” (Al-Hindawy, 1999: p. 7). The former are "the descriptive sentences that until Austin were the principal concern of philosophers of languagesentences that seem... to be employed mainly for saying something rather than doing something” (Sadock, 2006: p. 54); thus, they lend themselves to truth-falsehood values. The latter refer to those sentences the utterance of which denotes performing an action, thus they are either happy or unhappy depending on whether they meet a set of "happiness" or "felicity" conditions: a set of rules which "are associated with the valid performance of a speech act” (Jacobs, 2002: p. 231). Those conditions have been set by Austin in order to elicit the happy performance of ritual and archetypal performatives, such as wedding and christening a ship.

Accordingly, Austin (1962: pp. 14-15) lists these conditions as follows:

(A.1) There must exist an accepted conventional procedure having a certain conventional effect, that procedure to include the uttering of certain words by certain persons in certain circumstances, and further,

(A.2) the particular persons and circumstances in a given case must be appropriate for the invocation of the particular procedure invoked.

(B.1) The procedure must be executed by all participants both correctly and

(B.2) completely.

(Г.1) Where, as often, the procedure is designed for use by persons having certain thoughts or feelings, or for the inauguration of certain consequential conduct on the part of any participant, then a person participating in and so invoking the procedure must in fact have those thoughts or feelings, and the participants must intend so to conduct themselves, and further.

(Г.2) must actually so conduct themselves subsequently.

Later on, Austin has abandoned the constative-performative distinction to conclude that all utterances (i.e. constatives and performatives) have both a doing and a saying element at the same time, and their meaning is wholly dependent on the context in which they are issued (Al-Hindawi, 1999: p. 7). As such, he designs a new architecture of the acts employed in issuing performatives: locutionary, illocutionary and perlocutionary. Actually, Austin (1962: p. 148) justifies this shift by stating that:

The doctrine of the performative/constative distinction stands to the doctrine of locutionary and illocutionary acts in the total speech-act as the special theory to the general theory. And the need for the general theory arises simply because the traditional "statement" is an abstraction, an ideal, and so is its traditional truth or falsity. [sic]

As such, Austin has been aided by this distinction to get rid of the burden of citing a list of performative verbs (a task which he first claimed to implement, see p. 83ff, and p. 109ff). Instead, he discovers that what he really needs is a list of illocutionary forces of an utterance, as he (ibid.: 150) comments.

Consequently, he (ibid.: 151-164) classifies an illocutionary force into the following types: 
Verdictives: Typified, as the name suggests, by the giving of a verdict by a jury, arbitrator, or umpire. They need not be final; they may be, for instance, an estimate, reckoning or appraisal. Their main gist is giving a finding as to something, a fact or value, which is for different reasons hard to be certain about. Other examples are: characterize, diagnose, describe, analyze, and the like.

Exercitives: Refer to the exercising of powers, rights, or influence. Examples are: appointing, voting, ordering, urging, advising, warning, and the like.

Commissives: Taxonomized as such by committing someone to doing something (such as promising or undertaking), but include also declarations or announcements of intention, which are not promises, and also rather vague things which Austin calls espousals, as in siding with. Commissives have obvious connections with the two previous classes. Examples are: agree, pledge, engage, swear, favor, plan, and the like.

Behabitives: These are a very miscellaneous group which has to do with attitudes and social behavior. Examples are: apologizing, congratulating, commending, condoling, cursing, challenging and the like.

Expositives: These are difficult to define, as Austin himself admits. They make plain how our utterances fit into the course of an argument or conversation, how we are using words, or, in general, are expository. Examples are: I reply, I argue, I concede, I illustrate, I assume, I postulate, and the like.

In fact, Austin frankly states what he thinks of his classification: "I distinguish five very general classes: but I am far from equally happy about all of them” [sic], the thing which will be utilized later on by another scholar (See 1.2. below).

It has been aforementioned that Austin, at moving away from the constative/performative distinction, has proposed other acts of issuing an utterance: locutionary, illocutionary, and perlocutionary, so what is meant by each? Al-Hindawi (1999-12-13) summarizes what Austin (ibid.: 94-108) attempts to clarify about these:

a) Locutionary acts: They are roughly equal to uttering a certain sentence with a certain sense and reference. Austin gives this example to clarify more, he exemplifies a man who just witnessed a locutionary speech act and might describe it as follows:

He said to me "shoot her!" meaning by "shoot" shoot and referring by "her" her.

b) Illocutionary acts: These are conventional social acts recognized as such by both speaker and hearer. They happen in uttering something, for instance, issuing a command or a request, etc. To explain more, the man who witnessed the above "locutionary act" might describe the accompanied illocutionary act in the following way:

He urged (or advised, ordered, etc.) me to shoot her.

c) Perlocutionary acts: They refer to the effects of the utterance on the listener, that is, the change in the mind or behaviour of the listener as a result of producing locutions and illocutions. So, to proceed with Austin's instance, the same man who witnessed the two preceding acts might describe the resulting perlocution as follows:

He persuaded me to shoot her.

\subsection{Searle's Version}

After launching SATE in 1962, Searle, Austin's student, felt some need to develop this theory more, because of two main things. First, Austin's incomplete satisfaction with his own classification (See 2.1 above), and, second, the limitedness of his felicity conditions to produce happily the ritual and archetypal performatives only. Thus, these have inspired Searle to do two things:

a) Producing another set of felicity conditions that can cover all kinds of speech acts, due to the fact that when we speak we perform various types of functions: command, advice, thank, etc.

b) Developing the theory of speech acts, as Al-Hindawi (1999: p. 8) remarks, by presenting already existing ideas more systematically, and adding another type of speech acts: indirect speech acts.

As for the first, Searle has actually proposed a totally different set of felicity conditions, a one-size-fits-all set. That is, unlike Austin, Searle's felicity conditions can match all kinds of speech acts that are performed in our speech (not only ritual or archetypal), and that is why his set (and the developments he made) have overweighed Austin's and made what is understood by the theory nowadays attributed to Searle not Austin. So, Searle (1965, 1969) has first started by discussing the felicitous performance of promising and setting forth the following felicity conditions, which he, later on, has extended to cover performing different speech acts, as argued by Al-Hindawi (ibid.: 17). Searle's felicity conditions for “promise” are (it is to be noted that Searle's list is lengthy, see 1969: pp. 57-62, accordingly Al-Hindawi’s summary is presented here: pp. 17-18): 
Given that a speaker $\mathrm{S}$ utters a sentence $\mathrm{T}$ in the presence of a hearer $\mathrm{H}$, then in the literal utterance of $\mathrm{T}, \mathrm{S}$ non-defectively promises that $\mathrm{P}$ to $\mathrm{H}$, if and only if the following conditions obtain:

1. Propositional content rule: (i) "S expresses that $\mathrm{P}$ in the utterance of T".

(ii) "In expressing that $\mathrm{P}, \mathrm{S}$ predicates a future act $\mathrm{A}$ of $\mathrm{S}$ ".

2. Preparatory rules: (i) H would prefer S's doing A to his not doing A, and S believes $\mathrm{H}$ would prefer his doing A to his not doing A".

(ii) It is not obvious to both $\mathrm{S}$ and $\mathrm{H}$ that $\mathrm{S}$ will do A in the normal course of events".

3. Sincerity rule: "S intends that the utterance of T will make him responsible for intending to do A".

4. Essential rule: "S intends that the utterance of $T$ will place him under the obligation to do A".

As regards the second, Searle has done two things:

1. Offering another classification of the components of a speech act (1969: p. 24):

- Uttering words (morphemes, sentences) = performing utterance acts.

- Referring and predicting = performing propositional acts.

- Stating, questioning, commanding, promising, etc. = performing illocutionary acts.

Roughly speaking, Austin and Searle divide a speech act into three basic components (acts) which are mutually interdependent and which occur simultaneously:

Locutionary act: the act of saying something.

Illocutionary act: the act done in saying something.

Perlocutionary act: the act done by saying something.

(Van Eemeren \& Grootendorst, 1983: p. 26).

2. Reorganizing Austin's version more systematically by classifying speech acts into two types: direct and indirect. A direct speech act, as Quirk et al. (1985: p. 803) define it, is one where the structure matches the function, that is, a declarative, an interrogative, an imperative, and an exclamative issue a statement, a question, an order, and an exclamation respectively, syntactically speaking. In other words, direct speech acts are one-illocutionary force utterances, as commented by Al-Hindawi (1999: p. 34). Indirect speech acts, on the other hand, as Searle (1975: p. 59) elucidates them, are obtained if "a sentence that contains the illocutionary indicators for one kind of illocutionary act can be uttered to perform, IN ADDITION, another type of illocutionary act”. As such, indirect speech acts are two-illocutionary force utterances: one is literal (direct), the other non-literal (indirect).

e.g. Can you pass me the salt please?

In this utterance, the literal (secondary) force is a question which is not what is intended by the speaker (i.e. the speaker does not question the hearer's ability to pass the salt); rather, it is a request to pass the salt, and this is the primary force of the utterance.

Later on, Searle (1977: pp. 34-37, cited in Al-Hindawi: ibid.) has reclassified more consistently Austin's version of illocutionary forces. The most important criterion of his taxonomy is called direction of fit: "this has to do with whether the words are supposed to fit the facts of the world or whether the world is supposed to come to fit the words. There are four values: words-to-world, world-to-words, neither, and both” (Sadock, 2006: p. 65). By depending on this criterion, Searle distinguishes five functions of using language under which five classes of speech acts are classified. The functions are:

1. Saying how something is;

2. Trying to get people to do something,

3. Committing ourselves to doing something;

4. Expressing sentiments or attitudes; and

5. Bringing about changes in reality.

(Van Eemeren \& Grootendorst, 1983: p. 22).

The classes of speech acts are:

1. Representatives: Commit the speaker to the truth of the proposition expressed. In this class, the fit is between words and world. Examples are: asserting, concluding, complaining, etc.

2. Directives: Make the speaker intend to produce some effect through an action by the addressee. The fit is between world and words. Examples are: commanding, requesting, advising, etc.

3. Commisives: Commit the speaker to some future course of action, in which the fit becomes between world and words. Examples are: promising, offering, threatening, etc.

4. Expressives: As the name suggests, these are used to express the speaker's attitude towards a state of affairs 
which the speech act presupposes. In this class, no direction of fit exists. Examples are: thanking, apologizing, congratulating, etc.

5. Declarations: Require an extra linguistic institution which provides rules for their use. In this class, the fit is two-valued (words-to-world and world-to-words). Examples are: christening, wedding, dismissing, etc.

It can be concluded that the first seed of SATE is planted by Austin (1962) but watered and taken care of by Searle $(1969,1975,1977)$, metaphorically speaking. As such, the original (traditional) theory is associated with them both. However, the theory has been developed further by other scholars (See for instance, Katz, 1977, and Bach \& Harnish, 1979, and Van Eemeren \& Grootendorst, 1983), which is far beyond the scope of this paper.

After tackling SATE, which is a very familiar theory to all linguists, it is time to move to the second step, that is tackling the same theory in Arabic, in order to achieve the aim of this paper: showing which theory is older.

\section{Speech Act Theory in Arabic (SATA)}

Actually, SATA is foreshadowed by navigating through very reputable concepts in Arabic: constatives (Alkhabar) and performatives (Al-Inshaa'). Moreover, these two concepts have been approached variously by three types of scholars: grammarians, rhetoricians, and jurisprudents. It follows that constatives and performatives have undergone different treatments to accord with the purposes of each of these three, and accordingly, their study has been hyperlinked enough. However, the present paper will posit what is relevant to constatives and performatives (and consequently, SATA) as one whole entity, regardless of whether it is presented by grammarians, rhetoricians or jurisprudents, for all in all their opinions are complementary to each other, unless otherwise stated.

\subsection{Constatives and Performatives ${ }^{1}$}

To begin with, studies on this topic, as Matloob (1980: p. 86) points out, have been rooted in the scholastic theology, with no reference to a specific period of time to refer to. Moreover, he (ibid.) adds, revealing the Glourious Quran had an impact on approaching the topic, in which sophists proposed that the Glourious Quran had "commanded, prohibited and constated" [sic]. Hence, he (ibid.) concludes, this obviously negates the opinion supported by the majority of Muslim scholars, that the study of constatives and performatives dates back very much older than this (i.e. revealing the Glourious Quran). However, the study of Arabic rhetoric has been highlighted by as-Sakkaki, a late twelfth century Arab linguist, Al-Hindawi (1999: p. 9) argues, and detailed by Al-Jurjani (died in 471 or 474 A.H.). All the concepts presented in SATA are theirs: mainly the various taxonomy of constatives and performatives and violating the literal meaning of a constative. Later on, different studies have made their approach the point of departure without a further development of the theory, with one exception (Cf. 3.2 below).

\subsubsection{Constatives Defined}

A constative is an utterance that lends itself to truth-falsehood values (Matloob \& Al-Baseer, 1982: p. 106).

There have been different views, introduced by sophists, of a constative's truth-falsehood, as argued by Matloob (1980: pp. 86-87):

An absolute view ${ }^{2}$ : This twofold view, which is proposed by Nedhaam (died in 221 or 231 A.H.), suggests that the truth of a constative depends upon its fit to what the speaker believes (whether right or wrong). Its falsehood, on the other hand, is attained when there is no fit between what the speaker tells and believes. In other words, a constative is either right or wrong and nothing else, hence absolute.

A neutral view ${ }^{3}$ : This threefold view, which is attributed to Al-Jahidh (died in 255 A.H.), argues that a constative need not necessarily be true or false, it can be something in between. Consequently, he classifies constatives into: true, false, neither true nor false.

a. A true constative is one that fits the world (reality) with believing in this fit.

b. A false constative, in its turn, is normally the reverse of the true: one that does not fit the world with believing in this unfit.

\footnotetext{
${ }^{1}$ This terminology is adopted from Al-Masu'di (2012: p. 266) to create some unity of terminology because translating it individually will be quite distractive. Moreover, the verb constate will be used in relation to (Al-Khabar) and perform in relation to (Al-Inshaa'), as other translations are inaccurate, pragmatically speaking. For instance, Abdul-Raof (2006: pp. 287-290) uses "reporting” to refer the former and "informing" to the latter.

${ }^{2}$ Terminology is ours.

${ }^{3}$ These two views are the most common, for more views, see ibid.: 88.
} 
c. A neither-true-nor-false constative is sub-divided into:

-One that fits the world with believing that it does not.

-One that fits that world with no belief at all.

-One which does not fit the world with believing that it does.

-One that does not fit the world with no belief at all ${ }^{4}$.

This leads to a very interesting remark: though different from each other, both Nedhaam and Al-Jahidh have presented the notion of "direction of fit", with the former's being between the speaker and the word, and the latter's the world and the word, and the speaker.

However, it seems that the sophists have fired the imagination of different approaches to the topic: philosophical, persuasional, and above all lingisticians (Matloob \& Al-Baseer, 1982: p. 105).

As for linguists, Al-Juweini (1985: p. 11) remarks, there has been a consensus on two things when defining a constative: an utterance that lends itself to truth-falsehood values where there should be a direction of fit, which is either between:

- The speaker and the word (Nedhaam's view); or

- The speaker, the word, and the world (Al-Jahidh's view).

It remains a matter of personal choice whether one adopts either of these two views over the other.

\section{1) Types of Constatives}

When we constate, Ameen (1979: pp. 71-72) argues, our addressees will have various stands towards what we say: to believe, to doubt, or to deny. Accordingly, we should tailor what we constate depending on whether our addressee believes, doubts or denies, the thing which leads us to employ different strategies of constating, that is, employing emphasis or not. It follows that there are three types of constatives, as Matloob (1986: pp. 464-466) puts it:

a. Initial Constative: One with no emphasis at all due to the fact that the addressee, here, does not know, before, about the content of what is being constated:

e.g.

Rightness is worthier being followed ${ }^{5}$.

$$
\text { الحق أحق أن يتّبع }
$$

(ibid.; Khafaji \& Sharaf, 1990: p. 127).

b. Requestive Constative: One that employs one emphasis particle ${ }^{6}$ to eliminate any doubt or hesitation which the addressee shows.

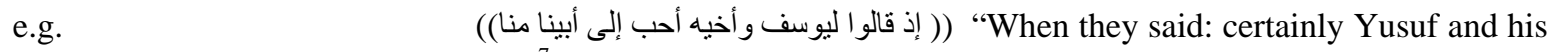
brother are dearer to our father than we"7 (cited in Matloob, 1980: p. 91).

c. Denial Constative: One which employs more than one emphasis particle in an attempt to persuade the denying addressee.

e.g. (إنكم لذائقو العذاب الأليم)) (Most surely you will taste that painful punishment”8.

It is to be noted that these types in tandem with their emphasis particles resemble, to some degree, the felicity conditions proposed by Austin and developed by Searle. This is justified by stressing the concept that as-Sakakki and Al-Jurjani (the presenters of these ideas as pointed out above, Cf. 3.1) paid attention to whether the speaker believes, doubts or denies and that speakers should take into their consideration this point in order to employ different strategies to eliminate any doubt or denial.

\section{2) Purposes of Constatives}

Ameen (1979: p. 56) affirms that if somebody constates something, then the addressee will either be ignorant (i.e. does not know in advance about what is being constated), as such one will constate something "new" to the addressee. For instance, if one says:

We will travel tomorrow, to someone who does not know in advance when travelling will be, then a constative here has a constative value, that is to say, it serves the purpose of constating new information to the addressee.

On the other hand, if the speaker does not constate any new information to the addressee, i.e. s/he tells something just for the sake of making the addressee know that the speaker also knows about that same thing, then a

\footnotetext{
${ }^{4}$ Nahla (1990: p. 42) has mathematically formulated Al-Jahidh's classification as follows: $1 .+$ world + belief $=$ true. $2 .-$ world + belief $=$ false. 3 . a) + world - belief $=$ neither true nor false; b) + world + no belief $=$ neither true nor false; c) - world + belief = neither true nor false; d) - world + no belief $=$ neither true nor false.

${ }^{5}$ Our translation.

${ }^{6}$ For an exhaustive list of emphasis particles, see Matloob, 1980: pp. 93-99.

${ }^{7}$ Suara: Yoosuf; Aya: 8. All the qura'nic verses in this paper are Shakir's translation.

${ }^{8}$ Sura: As's'aafaat; Aya: 38.
} 
constative becomes of a restricted value, as it communicates nothing new.

Actually, some comment should be made at this point. It does not seem quite reasonable that a speaker tells the addressee something just for the sake of showing that the speaker knows; it will be more convincing to argue that the speaker, by constating something already known to the addressee, intends something else, for example: (dis) praise, irony or sarcasm or anything else, due to the fact that language is not used in/for vacuum. Even if the speaker intends to tell the speaker that s/he knows, then that very intention also communicates something that could be elicited from the context. It might mean, for instance, that there is no need to tell me, I already know. What strongly supports this opinion is the fact that a constative may violate its literal meaning ${ }^{9}$ (to adopt Al-Hindawi's terminology: 1999: p. 9), to serve some metaphorical purpose (other than the two mentioned purposes) such as: praise, wish, command, prohibition, etc ${ }^{10}$, the fact that has been rightly rejected by Ameen (1979: p. 60). He confirms that a constative has two, and only two, purposes; whatever else is generated will be the offspring of these two. So, since a constative can violate its literal meaning, then its value cannot be restricted at all. And when a constative violates its literal meaning, Al-Hindawi (1999: p. 9) remarks, an indirect speech act is obtained.

\subsubsection{Performatives}

It has been pointed out before that the basic feature of an utterance to be called a constative is that it lends itself to truth-falsehood values (Cf. 3.1.1 above). A performative, by contrast, does not lend itself to those values because it has no world or "reality" to fit (Nahla, 1990: p. 81). In other words, a performative looks like something "newly born" by the speaker, as it were; so, the process of fit starts after making the utterance. Consequently, Matloob (1986: pp. 232-234) divides performatives into two types:

a. Requestive Performative: One that involves requesting something which does not exist at the time of requesting (hence it has no reality to fit, it creates the reality). It is classified into: imperative, negative imperative $^{11}$, interrogative, wish and vocative.

b. Non-Requestive Performative: Which requires nothing to request. Instead, it has to do with: contractual formula, astonishment, oaths, hope, and praise or dispraise. Matloob (1980: p. 110) pays heed to the point that this type has not attracted much attention because of its restricted purposes, unlike its counterpart. Accordingly, only the requestive performatives will be dealt with in detail below.

\section{Requestive Performatives}

Malik (1995: pp. 73-110) gives an illustrative account of the various types of requestive performatives, some of which are introduced below ${ }^{12}$ :

a. Imperative: An order to do something from a position of superiority and compulsion. Imperatives have two types of meanings: primary (direct) and secondary (indirect). The former refer to the demand of the execution of an action from a superior to an inferior, as in a mother commanding her son to eat:

e.g. Eat your food.

The latter, in turn, communicate a variety of meanings, some of which are:

Advice and Guidance:

e.g. ((يا بنيّ أقم الصلاة وأمر بالمعروف وانه عن المنكر))

"O my son! Keep up prayer and enjoin the good and forbid the evil”13

Prayer and Supplication:

e.g.

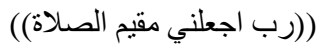

"My Lord, make me keep up prayer and from my offspring (too)"14

b. Negative Imperative: An order in the form of superiority and compulsion to refrain from doing an action. For instance, if a father wants his son to stop doing something, then he will say:

e.g. Stop doing that.

In this sense negative imperative can be counterpart term of "prohibition”. Some of the indirect meanings of a prohibition (negative imperative) are:

Advice and Guidance:

\footnotetext{
${ }^{9}$ See as-Sakkaki (p. 82) and Al-Jurjani (p. 211), as Matloob (1980: p. 102) instructs.

${ }^{10}$ For the exhaustive list, see: Matloob, 1980: pp. 103-105; Matloob \& Al-Baseer, 1982: pp. 118-120; Al-Juweini, 1985: pp. 12-15; Matloob, 1986: pp. 468-472; Nahla, 1990: pp. 48-50; and Khafaji and Sharaf, 1992: pp. 128-130.

${ }^{11}$ This is Malik's (1995) terminology.

${ }^{12}$ For the full discussion, see ibid. All the definitions and examples cited in this sub-section are his, some other are ours. When examples are ours, they will be italicized.

${ }^{13}$ Sura: Luqmaan, Aya: 17.

${ }^{14}$ Sura: Ibraaheem, Aya: 40.
} 
e.g. ulting overmuch surely Allah does not love any self-conceited boaster”15

Prayer and Supplication:

e.g.

$$
\text { (ربنا لا تزغ قلوبنا بعد إذ هديتنا)( }
$$

"Our Lord! make not our hearts to deviate after Thou hast guided us aright"16

c. Interrogative: A request for the knowledge about something which is unknown before. For example, when somebody asks someone else about the time:

e.g. Excuse me please, what time is it now?

Some of the indirect meanings of a question are:

Exclamation:

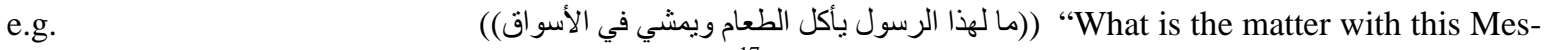
senger that he eats food and goes about in the markets"17

Order:

e.g.

"Will you then desist?",18

$$
\text { ((ف) (ف) أنتم منتهون) }
$$

d. Vocative: The speaker’s request for the attention of the addressee by the use of a vocative particle (أ، أي، يا، أيا). e.g. أ سكان هذا الحي خذوا حذركم

O people of this area, be careful.

Some of its indirect meanings are:

Friendliness and Politeness:

e.g.

Exaltation:

e.g.

to Allah"20

$$
\text { Yusuf! O truthful one!”19 }
$$

$$
\text { OO prophet! Be careful of your duty }
$$

e. Wish: A request for a thing whose existence is very desired. For example,

"O would that my people had known”21

$$
\text { ((با ليت قومي يعلمون)() }
$$

Unlike other types of requestive-performatives, wish does not have indirect meanings presented by itself. Ra-

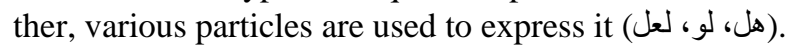

"Is there any way to return"22

$$
\text { ((هل إلى مرد من سبيل)( ل) ل) (هل) }
$$

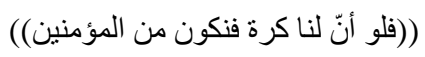

"But if we could but once return, we would be of the believers"23

“so that I may obtain knowledge of Musa's God”24.

$$
\text { ((لعلّي أطلّع إلى إله موسى)() }
$$

\subsection{Constatives and Performatives According to Najaf School of Jurisprudents}

This sub-section presents something different, yet complementary, to what has been discussed previously. It introduces the idea that there is no such division as constatives and performatives, as both are issued without lending themselves to truth-falsehood values. Moreover, whatever one issues can be considered a constative or a performative according to certain criteria. It will be proved that this opinion has preceded Austin’s in 1962.

Jamaludeen (1980: pp. 258-275) and Al-Khaleefa (2007: pp. 335-355) discuss in detail the opinions posited by the pioneers of the above mentioned ideas. They are: Al-khurasani (1839-1911), Al-Asfahani (died in 1941),

\footnotetext{
${ }^{15}$ Sura: Luqmaan, Aya: 18.

${ }^{16}$ Sura: Aali-E’mraan, Aya: 8.

${ }^{17}$ Sura: Al-Furqaan, Aya: 7.

${ }^{18}$ Sura: Al-Maaaida, Aya: 91.

${ }^{19}$ Sura: Yoosuf, Aya: 46.

${ }^{20}$ Sura: Al-A'hzaab, ya: 1.

${ }^{21}$ Sura: Yaaseen, Aya: 26.

${ }^{22}$ Sura: Ash-Shuraa, Aya: 44.

${ }^{23}$ Sura: Ash-Shoa'raa, Aya: 102.

${ }^{24}$ Sura: Al-Qas'as, Aya: 38.
} 
and Al-Khuii ${ }^{25}$. They institute, as Al-Khaleefa (ibid.) assures, what is called Najaf School of Constatives and Performatives. It is important to note that the opinions presented by them, especially by their leader Al-Khurasani, have preceded Austin's, due to the fact that Al-Khurasani had died in 1911, i.e. in the same year when Austin was born (ibid.). However, this paper presents Al-Khurasani's views only, since he is the leader of this school, and others' opinions are based on, if not derived from, his ${ }^{26}$.

Al-Khurasani's ideas can be summarized as follows: He argues for what is called "sense unity": an utterance has the same sense (that is locutionary act) whether what is said is a constative or a performative. What distinguishes each is what he highlights as "force", which resembles the western scholars' "illocutionary force". Al-Khurasani concludes that what makes an utterance a constative or a performative is not the act of saying it (i.e. the locutionary act), it is in the force that an utterance becomes either a constative or a performative. He also realizes that the "force" of an utterance is something which is outside merely saying the utterance. This means that Al-Khurasani, Al-Khaleefa (ibid.) proceeds, was the first to recognize that an utterance's force is arrived at by appealing to some extra-linguistic features: context of situation, speaker's intention, and the like. Put differently, Jamauldeen (1980: p. 276) asserts that jurisprudents were the first to distinguish between "utterance" (which they called المنطوق) and "force" (which they termed المفهوم).

This leads to the definite conclusion that Al-Khurasani was the first to attack dividing our utterances into constatives and performatives, for both have a saying element and a doing element. And this what gives him the priority over Austin in suggesting that all what we say is actually performing a certain kind of action on the basis of what we intend.

\section{SATE and SATA Contrasted}

1. Both English and Arabic study the utterance and not the sentence as far as it relates to speech act theory.

2. Both SATE and SATA have two versions: weak and strong. As for English, the weak version is represented by Austin's initial distinction between constatives and performatives, which has been neglected in favour of the stronger version. This latter, arrived at by Austin himself but developed further by Searle, proposes that there is no such a distinction, as all utterances have a doing element and a saying element. Arabic, on the other hand, manifests the reverse. Its weaker version is suggested by Najaf School of Jurisprudents, led by Al-Khurasani, that there is no such a distinction as constatives and performatives; their opinion is introduced a long time before Austin's, viz. 51 years. The strong version, which is proposed by Nedhaam and Al-Jahidh and their followers, confirms that such distinction does exist, hence the difference between English and Arabic. It is to be indicated that these views are classified as strong and weak due to what has become common about the theory in each language (i.e. it is common that English has no distinction, whereas Arabic has).

3. Both English and Arabic have direct and indirect speech acts. The difference lies in:

a. Arabic direct and indirect speech acts are presented earlier than their English counterparts. It is to be noted that the Arabic indirect speech acts have come along with the direct ones at the same time crystallized in what has been called "violating the literal meaning". The English ones, on the other hand, have been proposed by Searle as a further development of Austin's original theory. Besides, Searle's indirect speech acts have been given both separate classification of their own and more detailed tackling due to the fact that they are more widely used in actual use.

b. Arabic has five classes of direct speech acts: imperative, negative imperative, interrogative, wish, and vocative. English, by contrast, has only four: declarative, imperative, interrogative, and exclamative.

c. Arabic does not have a separate classification of indirect speech acts, unlike English where Searle has presented five classes: representatives, commisives, directives, expressive, and declarations.

d. Arabic indirect speech acts, unlike English, are arrived at by both constatives and performatives.

4. Arabic categorizes performatives into two types: requestive and non-requestive. All direct and indirect speech acts are the byproduct of requestive performatives. English does not have such a classification: it has direct and indirect speech acts only.

5. Both English and Arabic admit a set of felicity conditions for issuing an utterance. The difference lies in:

a. Arabic felicity conditions, proposed by as-Sakkaki and Al-Jurjani, are addressee-oriented, and are, in fact, psychological (as they appeal to belief, doubt, or denial). Moreover, they have been put forward for issuing a

${ }^{25}$ These dates are exactly what is cited in Al-Khaleefa (2007: p. 235).

${ }^{26}$ For more details, see Jamaludeen (1980: pp. 258-275) and Al-Khaleefa (2007: pp. 335-355). 
constative only. The English ones, on the other hand, are conventional and psychological (to christen a ship, or to perform a promise, respectively). Furthermore, they are speaker-oriented, and are appealed to for issuing a performative.

b. The western felicity conditions constitute the speech act itself without being concerned with the strategy of expressing it. Put differently, felicity conditions in the western theory show the successful composition of a speech act. Their Arabic counterparts manifest how a speech act is issued by means of a strategy: for instance, if the hearer is doubtful, then the speaker must use an emphatic particle to handle that doubt (Cf. 3.1.1.1 above).

6. It follows that Arabs have classified the addressee into three types: those who believe, doubt, or deny, whereas English have not.

7. The concept of "direction of fit" is presented by Arabs first, viz. Nedhaam and Al-Jahidh, to tackle two values of fit: between speaker and words (Nedhaam's), or between speaker, words, and the world (Al-Jahidh's). English, in its turn, has one concept of direction of fit proposed by Searle. There are four values of fit: words-toworld, world-to-words, neither, and both”.

8. English has classified the speech act (whether direct or indirect) into three (or four) components ${ }^{27}$ (locutionary, illocutionary, and perlocutionary), whereas Arabic has classified it into two only (locutionary and illocutionary). It follows that English has paid attention to the perlocutionary act, whereas Arabic has not.

9. Arab scholars have kept to as-Sakakki and Al-Jurjani's treatments of speech act theory without any attempt to develop it; English scholars, by contrast, have developed it further (Cf. 2.2 above).

\section{Conclusion}

It has been concluded that the Arabic version of the theory, though older it is, has the elements of maturity and depth of tackling more than its western peer. The only thing that makes the western version of the theory attract more attention is that it has been presented more systematically and clearly than its Arabic counterpart. It follows that the Arabic theory has been presented in a scattered manner on the hands of grammarians, rhetoricians, and jurisprudents. Moreover, the presentation of the theory on the hands of those people has complicated the theory more due to the different aims and angles from which each group approaches the theory. The western version of the theory has been delivered by philosophers, yet it has been included within linguistics via pragmatics, which breathes relevance to philosophy, but has been linguistically dressed, the thing which makes it rather easier to deal with.

\section{References}

Abdul-Raof, H. (2006). Arabic Rhetoric: A Pragmatic Analysis. London: Routledge.

Al-Hindawy, F. (1999). Iraqi EFL Learners' Use of the Speech Acts of “Command” and “Request”. Ph.D. Dissertation, Baghdad: University of Baghdad.

Al-Juweini, M. (1985). The Arabic Rhetoric: Authentication and Renewing. Alexandria: Al-Ma'arif.

Al-Khaleefa, H. (2007). Speech Act Theory between Modern Linguistics and the Linguistic Research in the Arabic and Islamic Heritage. Beirut: Lebanon Publishers.

Al-Masu'di, H. (2012). On Translating from English to Arabic. Amman: Darul Rudhwann.

Ameen, B. (1979). The Arabic Rhetoric in Its New Dress: Semantics, Part 1. Beirut: Darul Ilm Lilmalayeen.

Austin, J. (1962). How to Do Things with Words. Oxford: Clarendon Press.

Bach, K., \& Harnish, R. (1979). Linguistic Communication and Speech Acts. Cambridge: MIT Press.

Jacobs, S. (2002). Ch. 7: Language and Interpersonal Communication. In Handbook of Interpersonal Communication (3rd ed., pp. 213-240). California: Sage Publications, Inc.

Jamaludeen, M. (1980). The Syntactic Research of Jurisprudents. Baghdad: Darul Rasheed.

Katz, J. (1977). Propositional Structure and Illocutionary Force. New York: Crowell.

Khafaji, M., \& Sharaf, A. (1992). The Arabic Rhetoric between Imitation and Renewing. Beirut: Darul Jeel.

Levinson, S. (1983). Pragmatics. Cambridge: Cambridge University Press.

Littlejohn, S. (2003). Theories of Human Communication (7th ed.). Beijing: Tsinghua University Press.

\footnotetext{
${ }^{27}$ Al-Hindawi (1999: p. 14) highlights a fourth component, allocutionary act, of speech acts proposed by Haverkate 1979 . However, what is generally known that a speech act is constituted of the above mentioned components.
} 
Malik, F. (1995). Performative Utterances: Their Basic and Secondary Meanings with Reference to Five English Translations of the Meanings of the Holy Qur'an. Ph.D. Dissertation, Durham University.

Matloob, A. (1980). Rhetorical Devices. Kuwait: Printing Agengy.

Matloob, A. (1983). A Dictionary of Rhetorical Terms and Their Development, Part 1, Alf-Baa. Baghdad: The Iraqi Scientific Academy.

Matloob, A. (1986). A Dictionary of Rhetorical Terms and Their Development, Part 2, Taa'-Khaa'. Baghdad: The Iraqi Scientific Academy.

Matloob, A., \& Al-Baseer, K. (1982). Rhetoric and Application. Baghdad: Ministry of Higher Education and Scientific Research.

Nahla, M. (1990). On the Arabic Rhetoric: Semantics. Birut: Darul Uloomul Arabiya.

Quirk, R., Greenbaum, S., Leech, G., \& Svartvik, J. (1985). A Comprehensive Grammar of the English Language. London: Longman Group Limited.

Sadock, J. (2006). Ch. 3: Speech Acts. In The Handbook of Pragmatics (pp. 53-73). Malden: Blackwell Publishing Ltd. http://dx.doi.org/10.1002/9780470756959.ch3

Searle, J. (1969). Speech Acts: An Essay in the Philosophy of Language. Cambridge: Cambridge University Press. http://dx.doi.org/10.1017/CBO9781139173438

Searle, J. (1975). A Taxonomy of Illocutionary Acts. Language, Mind, and Knowledge, Minneapolis Studies in the Philosophy of Science, 7, 344-369.

The Glorious Qur'an. Translated by Shakir, M. (2008). Iran: Ansariyan Publications.

Van Eemeren, F., \& Grootendorst, R. (1983). Speech Acts in Argumentative Discussions. Dordrecht: Foris Publications. 